$4{ }^{1}$ Key Laboratory of Submarine Geosciences, State Oceanic Administration, 5 Hangzhou 310012, China.

$6 \quad{ }^{2}$ Second Institute of Oceanography, Ministry of Natural Resources, Hangzhou 7 310012, China.

$8{ }^{3}$ Institut de physique du globe de Paris, Université de Paris, CNRS, F-75005 9 Paris, France.

\section{Age of the Canada Basin, Arctic Ocean: Indications From} High-Resolution Magnetic Data
Tao Zhang ${ }^{1,2}$, Jérôme Dyment ${ }^{3}$, and Jinyao Gao ${ }^{1,2}$

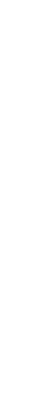

\section{Key Points:}

- High-resolution deep-tow and sea surface magnetic data in the ice-covered Canada Basin of the Arctic are presented.

- The crustal age of the Canada Basin is 139.5-128.6 Ma (142.4-132.8 Ma), with a spreading rate of $\sim 32(38) \mathrm{mm} / \mathrm{yr}$.

- The opening of the Canada Basin was roughly contemporaneous with the closure of the ancient South Anyui Ocean.

Abstract: The origin and history of the Amerasia basin are long-running debates, which hinder our knowledge of the Mesozoic tectonic configurations and geodynamic processes in the Arctic. This lack of knowledge is due in part to the paucity of accurate magnetic data in the ice-covered basin. Here, we identify the crustal age of the Canada Basin, a major part of the Amerasia Basin, through high-resolution 
23 deep-tow and sea surface magnetic data. The best fit of the four pairs of magnetic

24 lineations revealed by the high-resolution magnetic data is 139.5-128.6 Ma (or

25 142.4-132.8 Ma, depending on the geomagnetic polarity timescale). The crustal age

26 provides crucial constraints on the evolution of the circum-Arctic tectonic features

27 and generally supports the hypothesis that the opening of the Amerasia Basin is

28 related to the subductions during the closure of the South Anyui Ocean.

\section{Plain Language Summary}

31 The Amerasia Basin of the Arctic Ocean is one of the last major puzzles of the plate reconstructions, due to the lack of age knowledge. The identification of magnetic anomalies is the routine method of acquiring the age of oceanic crust, yet floating ice in the basin makes it difficult to obtain magnetic data. We collected deep-tow magnetic data in the basin by lowering a magnetic sensor to a depth of $\sim 2000 \mathrm{~m}$, which provides high-resolution data and avoids floating ice. The identified magnetic

37 lineations indicate the Amerasia Basin opened at 139.5-128.6 Ma (or 142.4-132.8 Ma,

38 depending on the geomagnetic polarity timescale). The contemporaneous closure of

39 the ancient South Anyui Ocean $(\sim 1000 \mathrm{~km}$ in the south) may have provided space for

40 the opening of the Amerasia Basin. This interpretation then generally supports the

41 existing hypothesis that the opening of the Amerasian Basin is associated with the

42 subduction process in the South Anyui Ocean. Nevertheless, a more sophisticated 43 geodynamical model is still needed. 
The opening of the Amerasia Basin shaped the Mesozoic configuration of major circum-Arctic geological features such as Arctic Alaska, Chukotka, and Arctic Canada. A robust tectonic model of the Amerasia Basin would yield insights into Arctic paleogeography, paleoclimate, the driving forces of the opening of the basin, and resource exploration within the dozens of circum-Arctic sedimentary basins [Shephard et al., 2013]. However, the nature and age of the Amerasia Basin have been debated for decades [e.g.,Embry, 1990, 2000; Grantz et al., 1998, 2011; Lane, 1997; Miller et al., 2006,2017]. Recently, the oceanic nature of the crust in the Canada Basin, which forms the major part of the Amerasia Basin, was revealed by refraction seismic data [Chian et al., 2016]. The roughly symmetric oceanic lithosphere about a N-S trending gravity low indicates that the Canada Basin was an E-W spreading oceanic basin. Nevertheless, the age of the Canada Basin remains elusive, with an inferred range of 160-72 Ma from investigations on the stratigraphy and volcanism along its margins and sparse geophysical data in the basin [e.g., Alvey et al., 2008; Chian et al., 2016; Døssing et al., 2013; Embry,1990; Gaina et al., 2014; Grantz et al., 2011; Lane,1997; Langseth et al., 1990; Miller et al., 2006, 2017; Taylor et al., 1981]. In particular, the low-resolution airborne magnetic data in the basin with an exceptionally thick $(4-11 \mathrm{~km})$ sedimentary cover impede the definitive identification of crustal age with magnetic anomalies. In this paper, we present recently sampled, high-resolution, deep-tow and sea surface magnetic data in the ice-covered Canada 

amplitude, shape, and pairs of the magnetic lineations. We discuss the relationships between seafloor spreading of the Canada Basin and regional unconformities along the margins of the Canada Basin. We further suggest that the opening of the Canada Basin may be kinematically and geodynamically related to the demise of the South Anyui Ocean, which partly supports the existing models [e.g., Koulakov et al., 2013;

71 Kuzmichev, 2009].

\section{Geological Settings}

Located at the center of the Arctic region, the Amerasia Basin is bounded by Arctic

1). Numerous models have been proposed to explain the formation of the Amerasia

Basin [e.g., Lawver and Scotese, 1990; and references therein]. The floating ice, thick sediment, and presence of the High Arctic Large Igneous Province make it difficult to validate those models. Among them, the generally accepted anticlockwise rotation model proposes that the Chukotka-Alaska region rotated from Arctic Canada with a pole of rotation located near the Mackenzie Delta in Early Cretaceous [Carey, 1955; Embry, 1990, 2000; Embry and Dixon, 1990; Grantz et al., 1998, 2011; Halgedahl and Jarrard, 1987; Mickey et al., 2002]. Recent seismic [Chian et al., 2016] and potential field data [Andersen et al., 2010; Gaina et al., 2011] from the Canada Basin revealed that the oceanic crust is roughly symmetrical about the N-S trending relict axis shown by a linear gravity low. The extent of oceanic crust and location of the 
relict axis are broadly consistent with the depictions in the rotation model. However, this model is challenged by alternative models [e.g., Chian et al., 2016; Døssing et al., 2018; Hutchinson et al., 2017; Koulakov et al., 2013; Lane, 199], in part due to the uncertain age of the Amerasia Basin. In the anticlockwise rotation model, the Amerasia Basin opened in two stages [e.g., Grantz et al., 2011]. The age of initial rifting ranges from the Early Jurassic (Hettangian) [Hubbard et al., 1987] to early Middle Jurassic (Aalenian) [Embry and Dixon, 1990; Mickey et al., 2002]. The second stage or main stage of opening is no older than Oxfordian-Tithonian (158-145.5), supported by the synrift sequence onlapping late Oxfordian-Tithonian strata at the Northwind Ridge [Grantz et al., 1998]. Nevertheless, the age of seafloor spreading is still highly controversial. Grantz et al.[2011] proposed that seafloor spreading was initiated in Hauterivian ( 131 Ma) after correlating the beds of the late synrift sequences to the widely distributed Lower Cretaceous unconformity. Halgedahl and Jarrard [1987] suggested that the Alaskan North Slope was still adjacent to the Arctic Islands in Valanginian based on the paleomagnetic data from the North Slope Kuparuk Formation. Embry and Dixon [1990] interpreted the Albian-Cenomanian unconformity in the Sverdrup Basin as the breakup unconformity. Based on a petrologic study, Miller et al. [2017] suggested that spreading in the Amerasia Basin may have ended at 90 Ma.

Several interpretations of the magnetic anomaly have been proposed in the Canada Basin based on available low-resolution airborne magnetic data. However, the 
107 low amplitude and limited two pairs of conjugate positive magnetic anomalies made

108 any oceanic crustal age identification uncertain and unreliable [Chian et al., 2016;

109 Gaina et al., 2014; Grantz et al., 2011; Taylor et al., 1981]. Taylor et al. [1981]

110 tentatively suggested that the crustal age of the Canada Basin ranges from the earliest

111 Late Jurassic to Valanginian (CM25-CM12, 160-136 Ma). Grantz et al. [2011] and

112 Chian et al. [2016] proposed similar identifications of chrons CM4n to CM2n

113 (131-127.5 Ma), with a spreading rate up to $75 \mathrm{~mm} / \mathrm{yr}$. Gaina et al. [2014] identified

114 CM16-CM4 (137.8-126.5 Ma) according to Channell (1995) and found a spreading

115 rate of $\sim 30 \mathrm{~mm} / \mathrm{yr}$ for the younger stage of seafloor spreading in the northern part of

116 the Canada Basin.

117 The morphology of the rift valley offers an independent constraint on the

118 spreading rate of the Canada Basin. Reflection seismic data indicate that the valley of

119 the relict ridge axis has depths of 1.0-1.5 km and widths of 30-40 km [Chian et al.,

120 2016; Grantz et al., 2011], which is typical for a slow spreading ( $<75 \mathrm{~mm} / \mathrm{yr}$ ) ridge

121 axis. The rough basement relief and relative thin crust (4-7 km) [Chian et al., 2016]

122 are also consistent with the characteristics of the slow to ultraslow spreading ridges

123 [Dick et al., 2003; Malinverno, 1991]. 


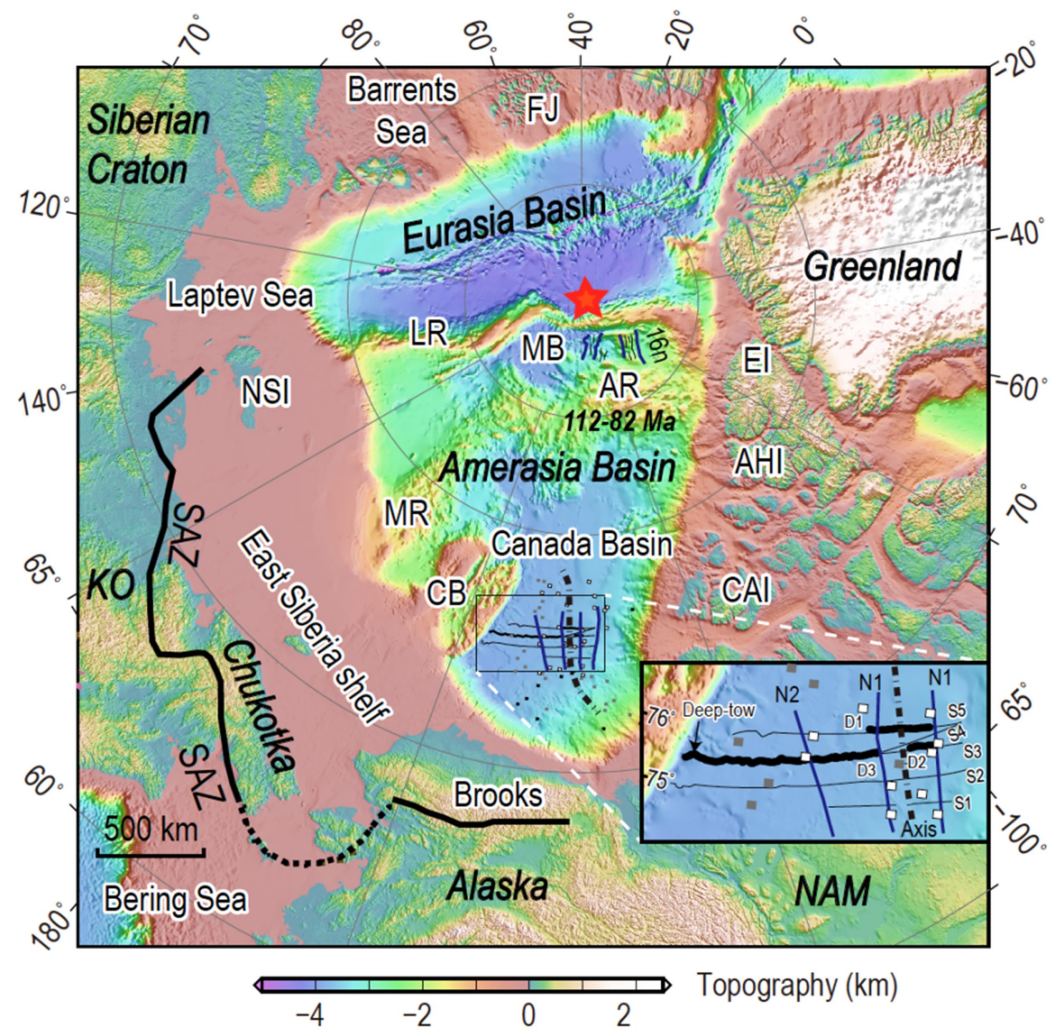

125 Figure 1. Topography of the Circum-Arctic Region. The location of SAZ is from Shephard et al.

126 [2013]. The location of the survey lines, relict ridge axis, and broad magnetic highs (N1 and N2)

127 are shown in the inset. $\mathrm{AHI}=$ Axel Heiberg Island; $\mathrm{AR}=$ Alpha Ridge; $\mathrm{CAI}=$ Canadian Arctic

128 Islands; $\mathrm{CB}=$ Chukchi Borderland; $\mathrm{EI}=$ Ellesmere Island; $\mathrm{FJ}=$ Franz Josef Land; $\mathrm{KO}=$

129 Kolyma-Omolon; LR = Lomonosov Ridge; MB = Makarov Basin; MR = Mendeleev Ridge; NAM

$130=$ North American craton; NSI = New Siberian Islands; SAZ = South Anyui suture Zone.

\section{Data acquisition and processing}

132 We use one deep-tow magnetic profile (consisting of three sections D1-D3) and five

133 sea surface magnetic profiles (S1-S5) at $75^{\circ}-76^{\circ} \mathrm{N}$ collected by Icebreaker "Xue Long"

134 in 2014 and 2016 to 2017, respectively (Figure 1). Most profiles are perpendicular to

135 the N-S trending gravity anomaly low near $142^{\circ} \mathrm{W}$. In the summer of $2014, \sim 500 \mathrm{~km}$ 
136 deep-tow magnetic data were sampled by a MarineMagnetics ${ }^{\mathrm{TM}}$ Overhauser 137 magnetometer with a sensitivity of $0.015 \mathrm{nT}$ mounted on a titanium-alloy frame and 138 towed $\sim 1.3 \mathrm{~km}$ above the seafloor at a speed of 2-3 knots (supporting information 139 Figure S1). To measure the depth of the frame, a pressure sensor Sea-Bird ${ }^{\mathrm{TM}} \mathrm{SBE}$ was 140 mounted on the wire at $5 \mathrm{~m}$ above the frame. Controlled by the payoff of the winch, 141 the depth of the magnetic sensor is $\sim 2.5 \mathrm{~km}$ in average and varies within a relatively 142 limited range of $\sim \pm 0.5 \mathrm{~km}$ (Figure S1).

143 The deep-tow magnetic data are processed with the following five steps. (1)

144 Magnetic data are merged with GPS position data and sensor depth data (Figure S1).

145 (2) The International Geomagnetic Reference Field (IGRF) [Thébault et al., 2015] is

146 removed. (3) The diurnal variations are removed. (4) The data are resampled to 147 equally spaced $(50 \mathrm{~m})$ points. (5) A Fourier transform method is used to 148 upward-continue the data from an uneven level to a constant depth of $2 \mathrm{~km}$ below 149 sea surface [Guspi, 1987]. Among these steps, steps 1, 2, and 4 have little effect on 150 the characteristics of magnetic data. For step 3, we use the magnetic variations 151 recorded at the Barrow and Resolution Bay magnetic observatories. Since the 152 survey area is approximately one-fourth between the two observatories, we use a 153 weighted average of Barrow (3/4) and Resolution Bay (1/4) magnetic data for the 154 diurnal correction. During collection of the deep-tow magnetic data, the daily 155 magnetic variation had amplitudes up to $\pm 100 \mathrm{nT}$ (Figures S2 and 2), with a 156 standard deviation of $40.8 \mathrm{nT}$. The daily magnetic variation is smaller but 
158 STD of $85.8 \mathrm{nT}$ (Figure S2). We remove all data with diurnal variation exceeding

$159 \pm 50 \mathrm{nT}$, although the deep-tow magnetic data are probably much less affected by

160 the ionospheric noise since this noise is attenuated by the conductive sea water

161 above [Miller, 1977]. After the diurnal correction, the upward-continued magnetic

162 anomaly to sea level fits well with the sea surface magnetic anomaly along the

163 same track collected in 2016 (Figure 2), indicating that the diurnal correction

164 efficiently reduce the associated external magnetic variations. In step 5, we remove

165 the signals with wavelengths longer than $100 \mathrm{~km}$ or shorter than $2 \mathrm{~km}$ and

166 upward-continued the magnetic data to $2 \mathrm{~km}$ below the sea surface, to obtain the

167 deep-tow magnetic anomaly $\sim 2 \mathrm{~km}$ above the sea floor and $\sim 7.5 \mathrm{~km}$ above the

168 igneous crust [Mosher and Hutchinson,2019].

169 Along the deep-tow magnetic survey in 2014, most tracks ( $>60 \%)$ were covered

170 by floating ice. Nevertheless, in the areas with light ice-conditions, we collected $\sim 110$

$171 \mathrm{~km}$ of sea surface magnetic data with a Cesium magnetometer towed $450 \mathrm{~m}$ behind

172 the $R / V$ "Xue Long”. In 2016 and 2017, the ice conditions were rather light ( $20 \%$ ice

173 coverage), which allowed us to collect $\sim 1400 \mathrm{~km}$ of sea surface magnetic data. The

174 associated International Geomagnetic Reference Field model [Thébault et al., 2015]

175 and the diurnal variations are also removed from the sea surface magnetic data

176 (Figure S2). For comparison, we also include the airborne magnetic anomaly data of

177 Taylor et al. [1981] in Figure 2. 
179 Two paired coherent broad magnetic highs are observed by the deep-tow, sea surface,

180 and airborne magnetic data (Figure 2). Here, we name them normal 1 (N1) and

181 normal 2 (N2) anomalies for the broad magnetic high close to and away from the

182 relict ridge axis, respectively. On the western flank, N1 with peak-to-trough

183 amplitudes of $150-200 \mathrm{nT}$ straddles $50-80 \mathrm{~km}$ in the sea surface magnetic data. N2 on

184 the western flank has larger amplitudes (up to $300 \mathrm{nT}$ ) and broader widths (90-120

$185 \mathrm{~km})$ than N1. The amplitudes of N1 and N2 are comparable to the magnetic signals

186 observed at other slow to ultraslow spreading ridges [e.g.,Gee and Kent, 2007]. The

187 two paired broad magnetic highs are roughly symmetrical with respect to the fossil

188 axis, suggesting that these magnetic anomalies may reflect geomagnetic reversals and

189 seafloor spreading in the Canada Basin. In addition, the power spectrum analysis of

190 the deep-tow magnetic data and surface magnetic data suggests that the magnetic

191 source layer is situated $10 \mathrm{~km}$ below the sea surface and then resides within the

192 igneous crust (Figure S3). Furthermore, the magnetic lineations are independent of the

193 gravity anomalies (Figure S4), which further implies that the magnetic lineations are

194 not associated with variations in the lithospheric structure. Therefore, the paired

195 magnetic lineations (N1 and N2) reflect spatial variations in crustal magnetization

196 associated with the record of magnetic field reversals within the oceanic crust.

197 Two pairs of magnetic anomalies are not sufficient for a unique, unambiguous

198 correlation with the geomagnetic polarity time scale (GPTS). In addition to N1 and 
199 N2, some previously undetected, spatially coherent, low amplitudes and 200 short-wavelength magnetic anomalies are also observed in the high-resolution 201 deep-tow magnetic data and to a lesser extent in the sea surface magnetic data (Figure 202 2). Such small magnetic anomalies could be related either to short geomagnetic 203 polarity intervals, excursions (i.e. aborted reversals) or paleointensity variations, 204 which would all be recorded in a similar way on both side of the (now fossil) ridge 205 axis, or by crustal tectonic processes, short-period external magnetic field fluctuations, 206 and/or artifacts during the data acquisition, which may have a different distribution. 207 Among them, two short-wavelength low-amplitude magnetic anomalies could be 208 ascribed to the geomagnetic variations, more likely to field reversals, considering 209 their repeatability and consistency between profiles and their presence on both flanks 210 of the relict ridge. Near the center of the broad magnetic low intervening N1 and N2 211 on the western flank, a narrow magnetic high with an amplitude of $200 \mathrm{nT}$ is 212 observed on the deep-tow magnetic profile (Figure 2). The amplitude of this anomaly 213 decreases to $\sim 50-100 \mathrm{nT}$ on the sea surface magnetic profiles. On the conjugate 214 eastern flank, a similar magnetic high is also present along three of the five sea 215 surface profiles. Thus, this magnetic high may be ascribed to a short normal polarity 216 interval in a relatively long period dominated by reversed polarities and is termed 217 small normal anomaly 1 (SN1). Besides, a magnetic low with an amplitude of $\sim 30 \mathrm{nT}$ 218 is observed near the center of N1 on the deep-tow magnetic anomaly on the eastern 219 flank (Figure 2c). This magnetic low is also observed on almost all sea surface 
220 magnetic profiles on the eastern flank of the ridge axis, except on profileS5. The

221 consistency between profiles on the eastern flank suggests that this magnetic low is

222 associated with one or a series of short reversed polarity intervals (termed SR1) in a

223 relatively long period dominated by normal polarity.

224 Encouraged by the consistency of the magnetic anomalies between profiles and

225 on conjugate flanks, we stack all the sea surface data and the upward-continued

226 deep-tow data to the sea surface in an attempt to enhance the signal/noise ratio and

227 better characterize the magnetic anomalies (Figure $2 \mathrm{f}$ ). We also stack the airborne

228 magnetic data by correlating N1 and N2 between these profiles (Figure 2f). Both

229 stacked data show that N2 has higher amplitude than N1 on both flanks of the fossil

230 ridge. We then identify the crustal age by fitting the observed anomaly and stacked

231 anomaly with synthetic magnetic anomalies computed from GPTSs. 


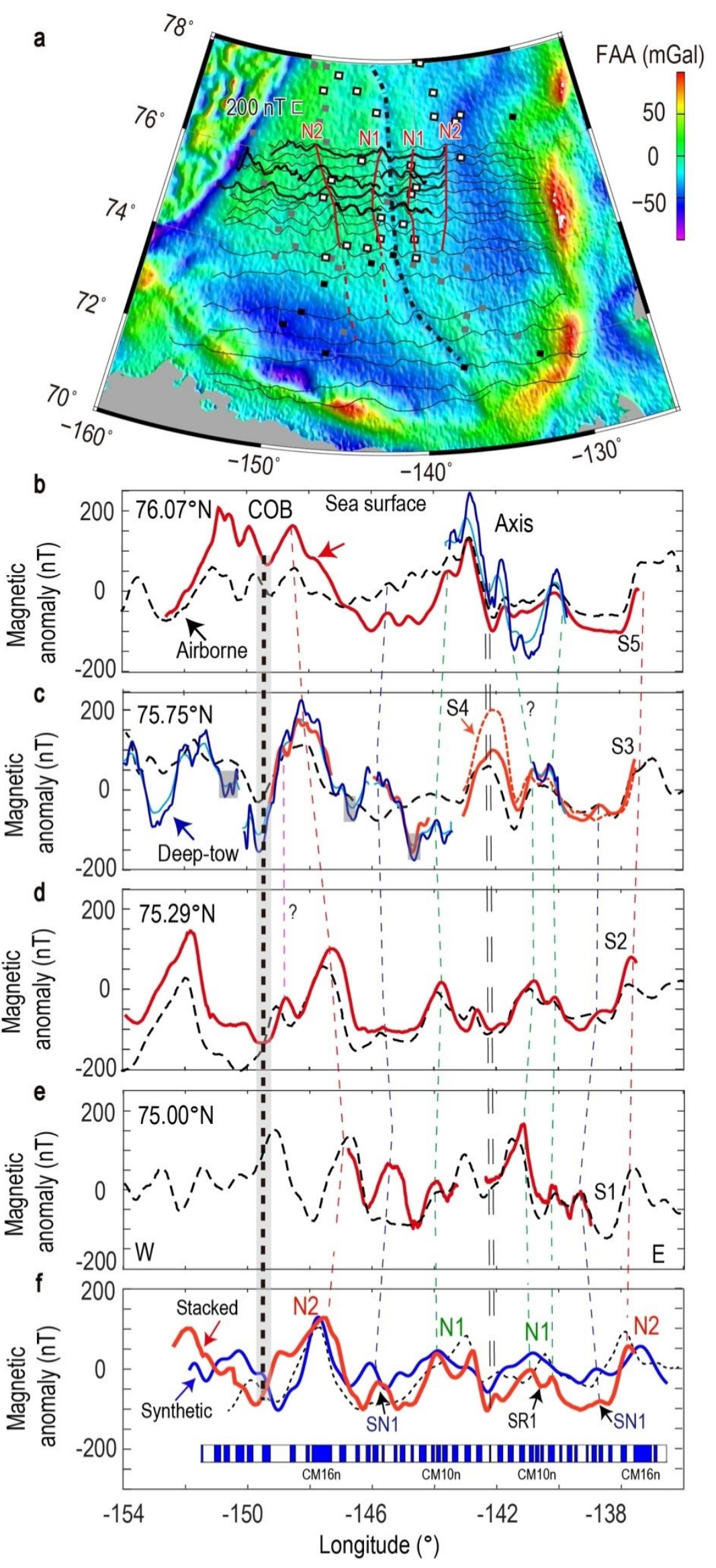

233 Figure2. Deep-tow and sea surface magnetic anomalies in the Canada Basin. (a) Deep-tow, sea 
surface, and airborne magnetic anomalies along their tracks. The background is based on the

235 satellite-derived free air anomaly data [Sandwell et al. 2014]. The continental, transitional, and oceanic crust identified from sonobuoy data [Chian et al., 2016] are shown in black, gray, and

237 white squares, respectively. The relict ridge axis is marked with a dashed line. (b-e) Deep-tow, sea

238 surface, and airborne magnetic anomalies at different latitudes. The upward continued deep-tow

239 data to sea surface and to $2000 \mathrm{~m}$ below sea surface are shown in light blue and blue, respectively.

240 The sea surface and airborne magnetic data are shown in red and black, respectively. The data 241 associated with diurnal variation $>50 \mathrm{nT}$ are marked with gray boxes. The profiles S2-S5 and 242 profile S1 are collected in 2016 and 2017, respectively. No reduction to the pole is necessary, as 243 the data are collected at high latitude. (f) Stacked sea surface (red), stacked airborne (black), and 244 best-fitting synthetic (blue) magnetic anomalies. The consistent magnetic anomalies between 245 profiles are linked with dashed lines. The magnetic bodies in MHTC12 [Malinverno et al., 2012] 246 that produce the synthetic magnetic anomaly at the depth of basement are also shown. For more 247 information on the correlation between the stacked magnetic anomaly and synthetic magnetic 248 anomalies, see the text and Figures S5-S6.

\section{Identification of magnetic anomalies}

250 Based on the onshore and along-margin geological evidences, the age of the Canada

251 Basin is not older than the Late Jurassic ( $\sim 160 \mathrm{Ma})$ and not younger than the Late

252 Cretaceous ( 72 Ma) [e.g., Embry, 1990; Gaina et al., 2014 ; Grantz et al., 2011 ; 253 Miller et al., 2006, 2017 ; Taylor et al., 1981]. Since the deep-tow magnetic anomalies 254 are rather strong (up to $400 \mathrm{nT}$ ) and well-marked, we do not expect that they formed 255 during the so-called "Jurassic quiet zone" (>157 Ma) characterized by numerous 256 polarity reversals and a weak geomagnetic intensity, or during the Cretaceous quiet 257 zone ( 120.6 (124)-83 Ma) characterized by a constant (or very dominant) normal 
258 polarity [Granot et al., 2012]. Neither the relatively long polarity intervals of chrons

$259 \mathrm{C} 32 \mathrm{n}-\mathrm{C} 33 \mathrm{n}$ nor the intervening excursions or intensity variations (the "tiny wiggles" 260 depicted by Bouligand et al. [2006]) produce the observed magnetic features. We 261 therefore restrict our investigations and compare the observed and stacked anomalies 262 with synthetic anomalies generated using the M-Series GPTS between the Jurassic 263 quiet zone and the Cretaceous quiet zone.

264 The positions of the continent-ocean boundaries on both flanks of the relict ridge 265 axis are derived from the sonobuoy data (Figure 1) [Chian et al., 2016]. The location 266 of the relict ridge axis is indicated by the $\sim 15 \mathrm{mGal} \mathrm{N}-\mathrm{S}$ trending gravity low 267 at $\sim 142^{\circ} \mathrm{W}$. We select the upper boundary of layer 2 (igneous basement) from the 268 sonobuoy data as the upper limit of the magnetic source [Chian et al., 2018; Mosher 269 and Hutchinson, 2019]. To produce sea surface anomalies with amplitudes up to 300 $270 \mathrm{nT}$ at $\sim 9.5 \mathrm{~km}$ above the magnetic sources, the thickness and magnetization of the 271 magnetic sources are assumed to be $1 \mathrm{~km}$ and $5 \mathrm{~A} / \mathrm{m}$, respectively. The mean 272 paleolatitude $\left(72^{\circ} \mathrm{N}\right)$ of the magnetized bodies is based on the paleolatitude $273\left(\sim 68^{\circ}-76^{\circ} \mathrm{N}\right)$ of the Alaskan North Slope between $120 \mathrm{Ma}$ and $150 \mathrm{Ma}$ [Seton et al., 274 2012]. Since there are still controversies about the age of CM0r, we adopt two GPTSs, 275 MHTC12 [Malinverno et al., 2012] for which the age of CM0r is 120.6 Ma, and 276 GTS2012 [Ogg, 2012] for which it is $\sim 125 \mathrm{Ma}$, to compute synthetic magnetic 277 anomalies (Figures S5 and S6).

278 We adopt both the cross-correlation [DeMets et al., 2010] and visual inspection 
279 methods to determine the best-fitting polarity reversal sequences (Figures S5 and S6).

280 Based on the least-square fitting criteria, the cross-correlation method quantitatively

281 compares the amplitude and shape of the part of the stacked magnetic anomalies

282 between the two broad magnetic highs (N1 and N2) with synthetic data (Figure S5).

283 In visual inspection method, we fit N1, N2, SN1, and SR1 of the observed data with

284 the synthetic magnetic anomalies.

285 Both methods give similar results: The synthetic data produced by the 286 CM7r-CM16n (CM17n?) sequences for both GPTSs are the best fit of the stacked 287 data (Figures $2 \mathrm{f}$ and S6). A series of normal polarity intervals of CM9n-11n and the 288 long CM16n produce $\mathrm{N} 1$ and N2, respectively. The CM13n and negative polarity 289 intervals between CM9 and CM11 are associated with the low-amplitude magnetic 290 high (SN1) intervening N1 and N2 and the low-amplitude magnetic low (SR1) near 291 the center of N1, respectively.

292 Therefore, the crustal age of the Canada Basin could be 139.5-128.6 Ma 293 (142.4-132.8 Ma) according to the MHTC12 (GTS2012), and seafloor spreading 294 occurred between Berriasian and Early Hauterivian (Figure S6). Near $75^{\circ} \mathrm{N}$, the 295 associated full spreading rate was $\sim 32$ (38) $\mathrm{mm} /$ year at the beginning of spreading and 296 slowed down to $\sim 30$ (30) $\mathrm{mm} /$ year in the last $\sim 3 \mathrm{Ma}$ before the cessation. Seafloor 297 spreading is slightly asymmetrical, with rates $5 \%$ faster on the western flank. Since 298 the distance between the lineations N2 on both flank is slightly larger in the north than 299 in the south (Figure 2a), the average spreading rates at the northern $\left(\sim 76.5^{\circ} \mathrm{N}\right)$ and 
southern $\left(\sim 74^{\circ} \mathrm{N}\right)$ limits of $\mathrm{N} 2$ are inferred to be $34.5(39.0)$ and $28.3(31.9) \mathrm{mm} / \mathrm{year}$,

301 respectively. The slow spreading rate is consistent with the presence of the $\sim 1.5$

$302 \mathrm{~km}$-deep rift valley and the 4-6 km thin crust in the Canada Basin. Since there are no

303 robust constraints such as fracture zones on the spreading direction, we calculate the

304 spreading rate assuming an orthogonal spreading. Recently, opening models of the

305 Amerasia Basin involving a strike-slip component (oblique spreading or

306 transtensional deformation) have been proposed based on northeast-treading structural

307 fabrics [Døssing et al., 2018; Hutchinson et al., 2017]. The highly oblique spreading

308 (up to $\sim 50^{\circ}$ ) requires a spreading rate $\sim 1.5$ times faster than that estimated from the

309 magnetic lineations. In this case, the spreading rate we estimated corresponds to the

310 effective spreading rate termed by Dick et al. [2003] and still matches the deep rift

311 valley and thin crust in the Amerasia Basin. Among numerous proposed crustal ages

312 from magnetic data, our result agrees better with the crustal age of 137.8-126.5 Ma

313 proposed by Gaina et al. [2014]. As the seismic reflection data show that the synrift

314 sequences overlap late Oxfordian-Tithonian ( 158-145.5 Ma) marine shelf or shelf

315 basin deposits in three piston cores on the Northwind Ridge [Grantz et al., 1998,

316 2011], we further infer that the main stage of opening of the Canada Basin may had

317 been fulfilled by rifting from late Oxfordian-Tithonian to Berriasian and the

318 consequent seafloor spreading until early Hauterivian.

\section{Discussion}

320 Three main regional unconformities (late Callovian-early Oxfordian, late 
321 Hauterivian, and mid-Aptian) were interpreted as the breakup unconformity and were

322 used to date the initial seafloor spreading of the Canada Basin by various authors

323 [Embry and Dixon, 1990; Grantz et al., 2011; Grantz and May, 1982; Hubbard et al.,

324 1987]. However, the seafloor spreading during Berriasian-early Hauterivian of the

325 Canada Basin suggests that the relationships between those regional unconformities

326 along the margins and the initiation of seafloor spreading in the Amerasia Basin

327 cannot be steadily associated. The thinned continental crust and transitional crust in

328 the Canada Basin could be as wide as $300 \mathrm{~km}$ [Chian et al., 2016]. During the

329 formation of such wide margins, sequential active faulting may have migrated toward

330 the future oceanic crust [Brune et al., 2014]. Therefore, further evidences, such as the

331 reflection seismic data from the Canada Basin to the areas of the regional

332 unconformities, are needed to address the relationship between the regional

333 unconformities and the breakup event. Even so, part of the rifted margins of the

334 Canada Basin were already subaquatic at the time of the breakup [Grantz et al., 2011],

335 which may further obscure the identification of the breakup unconformity [Franke,

336 2013].

337 The crustal age of the Canada Basin also provides further kinematic and

338 geodynamic implications for the Mesozoic circum-Arctic region. Between Late

339 Jurassic and Early Cretaceous, the Arctic Alaska and Chukotka blocks experienced

340 intense tectonic activity, including collision between the Alaska- Chukotka and the

341 Kolyma-Omolon blocks to the south, the associated closure of the South Anyui Ocean 
342 (SAO), and the closure of the Angayucham Ocean (Figure 3). The subductions that 343 consumed the SAO have been postulated as the source of driving force for the 344 opening of the Amerasia Basin based on tomography images [e.g., Gaina et al., 2014; 345 Koulakov et al., 2013] and the range of South Anyui suture zone [Kuzmichev, 2009].

346 Our results further show that the opening of the Canada Basin was roughly 347 contemporaneous with the closure of the SAO and the associated subductions. At the 348 beginning of the main rifting stage of the Canada Basin $(\sim 158 \mathrm{Ma})$, the closure of 349 SAO was initiated by southward and northward subductions (Figure 3a), as indicated 350 by the ages of the Oloy Arc ( 160-140 Ma) in the south and the Nutesyn Arc $351(\sim 160-150 \mathrm{Ma})$ in the north, respectively [Amato et al., 2015; Layer et al., 2001; 352 Shephard et al., 2013]. The final stage of the closure of the SAO was fulfilled by the 353 collision between the Chukotka and Kolyma-Omolon blocks. Although the collision 354 mainly occurred between 119 and $106 \mathrm{Ma}$ [Amato et al., 2015; Miller et al., 2009; 355 Sokolov et al., 2002, 2009], it may started as early as 130-124 Ma [Layer et al., 2001; 356 Toro et al., 2003], which also coincide with the cessation of the seafloor spreading in 357 the Canada Basin at 128.6 Ma. This temporal and spatial consistency lead us to 358 suggest that the closure of the SAO provided space for the opening of the Canada 359 Basin, and the collision between the Chukotka and Kolyma-Omolon blocks at the 360 final stage of the SAO closure terminated the seafloor spreading of the Canada Basin.

361 This inference then generally supports the idea that the opening of the Canada Basin 362 is associated with the subduction process in the SAO [Koulakov et al., 2013; 
364 an overall higher opening rate in the southern part of the Canada Basin [Koulakov et 365 al., 2013]. As “a common back-arc basin" proposed by Kuzmichev [2009], the Canada 366 Basin was also too far away (more than $1,000 \mathrm{~km}$ ) from the subduction zones in the 367 SAO, since a back-arc spreading center is usually limited to a distance of $200-300 \mathrm{~km}$ 368 from a trench [e.g., Toksöz \& Hsui, 1978[. Further information on the geometry, 369 extent, and polarity reversals of the subductions in the SAO may help to refine a more 370 comprehensive geodynamic model to address these issues.
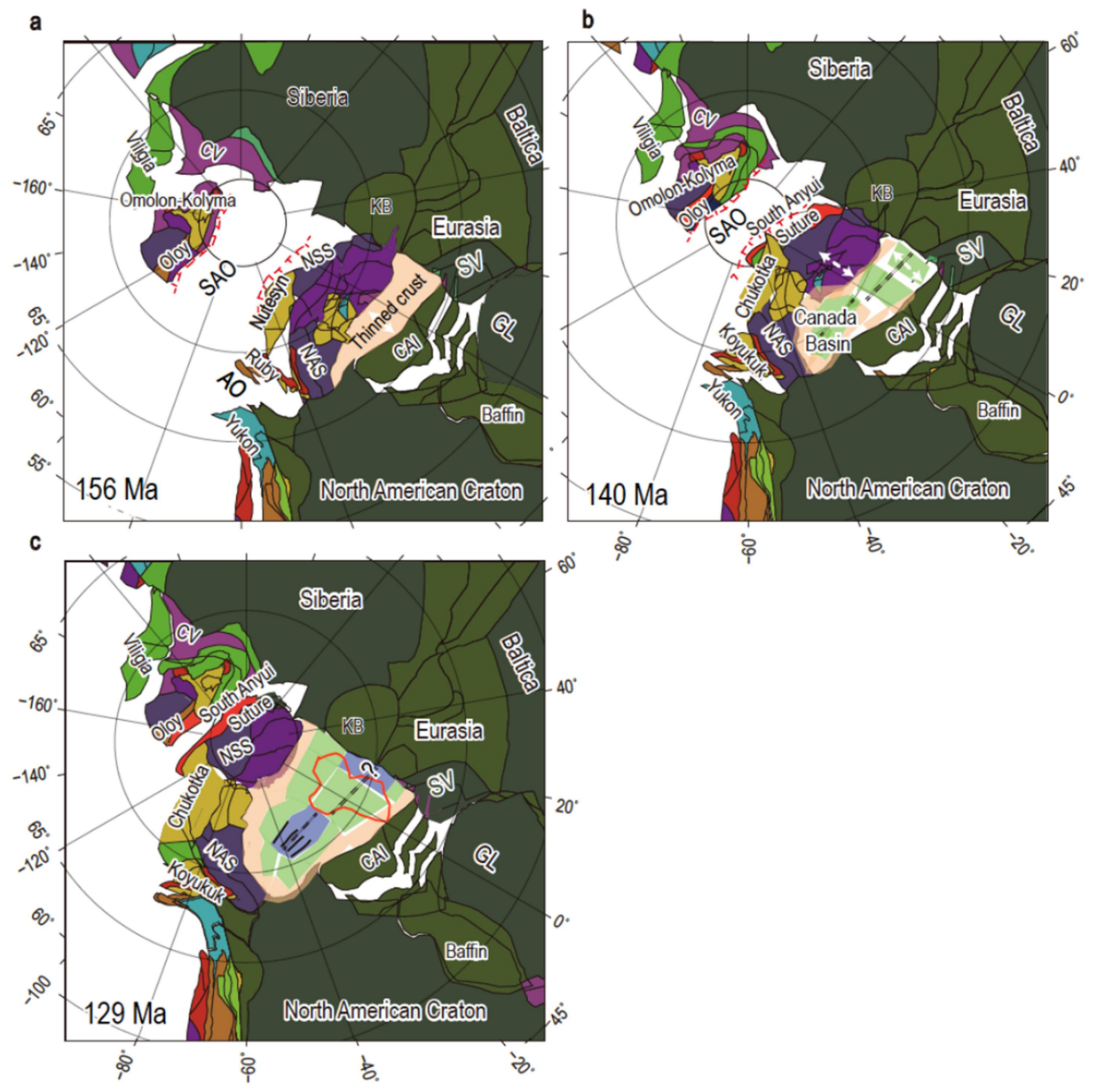

372 Figure3. Plate reconstructions of the circum-Arctic Region between $156 \mathrm{Ma}$ and $129 \mathrm{Ma}$. The

373 shapes of the geological features are based on Müller et al. [2016]. (a) Rifting created the 
374 Amerasia Basin. The South Anyui Ocean was then subducting to the south and north. East of the

375 SAO, the Angayucham Ocean (AO) and associated Koyukuk Arc (initiated at $\sim 160-145 \mathrm{Ma}$ ) are

376 believed to be the eastern extensions or the counterparts of the SAO and Nutesyn Arc [Amato,

377 2004, 2015; Churkin et al., 1981; Nokleberg et al., 2000], respectively. (b) Initial seafloor

378 spreading in the Amerasia Basin. (c) Seafloor spreading cessation in the Amerasia Basin. The

379 position of the future Alpha Ridge is marked by a red line. Since the position and geometry of the

380 Chukchi Borderland in Mesozoic remain controversial [Grantz et al., 1998; Hutchinson et al.,

3812017 ; Miller et al., 2006], we only place the CBL in (c) according to its present configuration. The

382 rifting direction in strike-slip models is shown in dashed arrow along the eastern boundary of the

383 Northwind Ridge [Døssing et al., 2018; Hutchinson et al., 2017]. Note the northeast-trending

384 strike slip is subparallel to the subduction zones in the SAO, which may require a new explanation

385 about the dynamic relationship between them. The inferred thinned continental crust, transitional

386 crust, and oceanic crust in the Canada Basin are marked with brown, green, and blue, respectively.

$387 \mathrm{CBL}=$ Chukchi Borderland; $\mathrm{CV}=$ Central Verkhoyansk; $\mathrm{GL}=$ Greenland; $\mathrm{KB}=$ Kara Block;

388 NAS $=$ North Alaska Slope; NSS $=$ Northern Siberia Shelf; SAO $=$ South Anyui Ocean; SV $=$

389 Svalbard.

391 Acknowledgments

392 The authors thank the captain Quan Shen and all the crews of the R/V "Xue Long".

393 We benefit from discussion with Min Ding, Weiwei Ding, and Zhaocai Wu. We are

394 grateful to Carmen Gaina and an anonymous reviewer, whose thorough reviews have 
395 greatly improved the manuscript. This work is supported by the National Natural 396 Science Foundation of China (grant 41576065), the Scientific Research Fund of the 397 Second Institute of Oceanography, SOA (grant QNYC201503), and the Chinese Polar 398 Environment Comprehensive Investigation and Assessment Programs (grant 399 CHINARE03-03). There is no financial conflict of interest for any author. The 400 magnetic data is available at https://github.com/yangchunguo/ DataCiteRepository.

\section{$401 \quad$ References}

402 Alvey, A., C. Gaina, N. Kusznir, and T. Torsvik (2008), Integrated crustal thickness mapping and 403 plate reconstructions for the high Arctic, Earth and Planetary Science Letters, 274(3-4), 404 310-321. https://doi.org/10.1016/j.eps1.2008.07.036

Amato, J. M., J. Toro, V. V. Akinin, B. A. Hampton, A. S. Salnikov, and M. I. Tuchkova (2015), Tectonic evolution of the Mesozoic South Anyui suture zone, eastern Russia: A critical 1530-1564. https://doi.org/10.1130/GES01165.1

Amato, J. M., J. Toro, T. E. Moore, A. J. Sussman, and A. B. Weil (2004), Origin of the Bering Sea salient, in Orogenic curvature: Integrating paleomagnetic and structural analyses, In A. J. Sussman, Arlo, B, Weil (Eds), Orogenic curvature: Integrating paleomagnetic and structural

414 Andersen, O. B., Knudsen, P., \& Berry, P. A. (2010). The DNSC08GRA global marine gravity 
417 Bouligand, C., J. Dyment, Y. Gallet, and G. Hulot (2006), Geomagnetic field variations between chrons 33r and 19r (83-41 Ma) from sea-surface magnetic anomaly profiles, Earth and Planetary Science Letters, 250(3-4), 541-560. https://doi.org/10.1016/j.epsl.2006.06.051

Brune, S., C. Heine, M. Pérez-Gussinyé, and S. V. Sobolev (2014), Rift migration explains continental margin asymmetry and crustal hyper-extension, Nature Communications, 5, 4014.https://doi.org/10.1038/ncomms5014

Carey, S. W. (1955), The orocline concept in geotectonics-Part I, Papers and proceedings of the Royal Society of Tasmania, 80: 255-288.

Channell, J. E. T. (1995). Recalibration of the geomagnetic polarity timescale. Reviews of Geophysics, 33(S1), 161-168. https://doi.org/ 10.1029/95RG00404

Chian, D., H. R. Jackson, D. R. Hutchinson, J. W. Shimeld, G. N. Oakey, N. Lebedeva-Ivanova, Q. Li, R. W. Saltus, and D. C. Mosher (2016), Distribution of crustal types in Canada basin, Arctic Ocean, Tectonophysics, 691, 8-30. https://doi.org/10.1016/j.tecto.2016.01.038

Churkin, M., and J. H. Trexler (1981), Continental Plates and Accreted Oceanic Terranes in the Arctic, In A. E. M. Nairn, M. Churkin, F. G. Stehli (Eds.), The Arctic Ocean (pp. 1-20). US,

DeMets, C., R. G. Gordon, and D. F. Argus (2010), Geologically current plate motions, 
438 Døssing, A., Gaina, C., Andersen, O. B., \& Jackson, R. (2018). New details on Cretaceous ocean formation in the High Arctic based on satellite gravity data. Paper presented at the International Conference on Arctic Margins (ICAM VIII) Abstracts, Stockholm, Sweden.

441 Døssing, A.,C. Gaina, J. M. Brozena (2017), Building and breaking a large igneous province: An example from the High Arctic. Geophysical Research Letters, 44(12), 6011- 6019. https://doi.org/10.1002/2016GL072420

444 Døssing, A., H. R. Jackson, J. Matzka, I. Einarsson, T. M. Rasmussen, A. V. Olesen, and J. Brozena (2013), On the origin of the Amerasia Basin and the High Arctic Large Igneous 219-230. https://doi.org/10.1016/j.eps1.2012.12.013

Embry, A. (2000), Counterclockwise rotation of the Arctic Alaska Plate: best available model or untenable hypothesis for the opening of the Amerasia Basin, Polarforschung, 68, 247-255.

Embry, A. F. (1990), Geological and geophysical evidence in support of the hypothesis of anticlockwise rotation of northern Alaska, Marine Geology, 93, 317-329. https://doi.org/ $10.1016 / 0025-3227(90) 90090-7$

Embry, A. F., and J. Dixon (1990), The breakup unconformity of the Amerasia Basin, Arctic Ocean: Evidence from Arctic Canada, Geological Society of America Bulletin, 102(11), 1526-1534. https://doi.org/10.1130/0016-7606(1990)102<1526:TBUOTA>2.3.CO;2

456 Franke, D. (2013). Rifting, lithosphere breakup and volcanism: Comparison of magma-poor and 
Gaina, C., Medvedev, S., Torsvik, T. H., Koulakov, I., \& Werner, S. C. (2014). 4D Arctic: A glimpse into the structure and evolution of the Arctic in the light of new geophysical maps, plate tectonics and tomographic models. Surveys in Geophysics, 35(5), 1095-1122. https://

Gaina, C., Werner, S. C., Saltus, R., \& Maus, S. (2011). Circum-Arctic mapping project: New 464 doi.org/10.1007/s10712-013-9254-y

467 Gee, J. S., and D. V. Kent (2007), Source of oceanic magnetic anomalies and the geomagnetic 468 polarity time scale, In M. Kono (Ed), Treatise on Geophysics: Geomagnetism(Vol. 5, pp. 469 455-507).Elsevier. https://doi.org/10.1016/B978-044452748-6/00097-3

470 Granot, R., Dyment, J., \& Gallet, Y. (2012). Geomagnetic field variability during the Cretaceous 471 Normal Superchron. Nature Geoscience, 5(3), 220-223. https://doi.org/10.1038/NGEO1404

472 Grantz, A., D. Clark, R. Phillips, S. Srivastava, C. Blome, L. Gray, H. Haga, B. Mamet, D. 473 McIntyre, and D. McNeil (1998), Phanerozoic stratigraphy of Northwind Ridge, magnetic 474 anomalies in the Canada basin, and the geometry and timing of rifting in the Amerasia basin, Arctic Ocean, Geological Society of America Bulletin, 110(6), 801-820. 477 Grantz, A., P. E. Hart, V. A. Childers, A. M. Spencer, A. F. Embry, D. L. Gautier, A. V. Stoupakova, 478 and K. Sørensen (2011), Geology and tectonic development of the Amerasia and Canada 

of London. https://doi.org/10.1144/M35.50

Grantz, A., and S. D. May (1982), Rifting History and Structural Development of the Continental Margin North of Alaska, In J. S. Watkins, C. L. Drake (Eds.), Studies in Continental Margin Geology (Vol. 34, pp. 77-100), Tulsa,OK:American Association of Petroleum Geologists. https://doi.org/10.1306/M34430C4

Guspi, F. (1987), Frequency-domain reduction of potential field measurements to a horizontal plane, Geoexploration, 24(2), 87-98.https://doi.org/10.1016/0016-7142(87)90083-4

Halgedahl, S., and R. Jarrard (1987), Paleomagnetism of the Kuparuk River Formation from Weimer (Eds.) Alaskan North Slope Geology (Vol.2, pp. 581-617). Bakersfield, CA: Pacific Section, Society of Economic Paleontologists and Mineralogists.

Hubbard, R. J., S. P. Edrich, and R. P. Rattey (1987), Geologic evolution and hydrocarbon habitat of the 'Arctic Alaska microplate', Marine and Petroleum Geology, 4(1), 2-34. https://doi.org/10.1016/0264-8172(87)90019-5 Chian, R. W. Saltus, and G. N. Oakey (2017), Significance of Northeast - Trending Features in Canada Basin, Arctic Ocean, Geochemistry, Geophysics, Geosystems, 18(11), 4156-4178. https://doi.org/10.1002/2017GC007099

499 Koulakov, I. Y., Gaina, C., Dobretsov, N., Vasilevsky, A., \& Bushenkova, N. (2013). Plate 
Kuzmichev, A. B. (2009). Where does the South Anyui suture go in the New Siberian islands and Laptev Sea?: Implications for the Amerasia basin origin. Tectonophysics, 463(1), 86-108. https://doi.org/10.1016/j.tecto.2008.09.017

Lane, L. S. (1997), Canada Basin, Arctic Ocean: evidence against a rotational origin, Tectonics, 16(3), 363-387. https://doi.org/10.1029/97tc00432

Langseth, M. (1990), Geothermal observations in the Arctic region, In A. Grantz, G. L. Johnson, J. of America. https://doi.org/10.1130/DNAG-GNA-L.133

511 Lawver, L., and C. Scotese (1990), A review of tectonic models for the evolution of the Canada Basin, In A. Grantz, G. L. Johnson, J. F. Sweeney, (Eds), The Arctic Ocean Region (pp. https://doi.org/10.1130/DNAG-GNA-L.593 setting of the plutonic belts of Yakutia, northeast Russia, based on 40Ar/39Ar geochronology 593-618). Boulder, CO: Geological Society of America. 
521 Malinverno, A., J. Hildebrandt, M. Tominaga, and J. E. Channell (2012), M - sequence 522 geomagnetic polarity time scale (MHTC12) that steadies global spreading rates and incorporates astrochronology constraints, Journal of Geophysical Research, 117(B6). https://doi.org/10.1029/2012JB009260

Mickey, M. B., A. Bymes, and H. Haga (2002), Biostratigraphic evidence for the prerift position CO: Geological Society of America. https://doi.org/10.1130/0-8137-2360-4.67

Miller, E., S. Katkov, A. Strickland, J. Toro, V. Akinin, and T. Dumitru (2009), Geochronology and thermochronology of Cretaceous plutons and metamorphic country rocks, Anyui-Chukotka fold belt, North East Arctic Russia,In: D.B.Stone, K.Fujita, P.L.Layer, E.L.Miller, A.V. Prokopiev,J.Toro(Eds), Geology, Geophysics and Tectonics of Northeastern Russia: a Tribute to Leonid Parfenov(Vol. 4, pp. 223-241).Copernicus, Göttingen: European Geosciences Hoiland, T. M. O'Brien, A. Soboleva, and J. Toro (2017), Circum-Arctic Lithosphere Union. https://doi.org/10.5194/smsps-4-157-2009 Evolution (CALE) Transect C: displacement of the Arctic Alaska-Chukotka microplate towards the Pacific during opening of the Amerasia Basin of the Arctic, In V. Pease,B. Coakle (Eds), Circum-Arctic Lithosphere Evolution (Vol. 460, pp. 57-120), London: Geological Society, London. https://doi.org/10.1144/SP460.9 

https://doi.org/10.1029/2005TC001830

Miller, S. P. (1977), The validity of the geological interpretations of marine magnetic anomalies, Geophysical Journal of the Royal Astronomical Society, 50(1), 1-21. https://doi.org/10.1111/j.1365-246x.1977.tb01320.x Kaminsky (Eds.), Geologic Structures of the Arctic Basin (pp. 295-325), Springer. https://doi.org/10.1007/978-3-319-77742-9_10

\section{2}

Müller, R. D., M. Seton, S. Zahirovic, S. E. Williams, K. J. Matthews, N. M. Wright, G. E. evolution and global-scale plate reorganization events since Pangea breakup, Annual Review

$$
\begin{array}{llll}
\text { of } \text { Earth } \quad \text { and } \quad \text { Planetary } & \text { Sciences, } & \text { 44, }
\end{array}
$$

557 Nokleberg, W. J. (2000), Phanerozoic tectonic evolution of the Circum-North Pacific, US Department of the Interior, US Geological Survey Open File Report, 98-754. https://doi.org/10.3133/pp1626

Ogg, J. (2012), Geomagnetic polarity time scale, In F. M. Gradstein, J. G. Ogg, M. D. Schmitz, G. 
Sandwell, D. T., R. D. Müller, W. H. Smith, E. Garcia, and R. Francis (2014), New global marine gravity model from CryoSat-2 and Jason-1 reveals buried tectonic structure, Science, 346(6205), 65-67. https://doi.org/10.1126/science.1258213

Seton, M., R. Müller, S. Zahirovic, C. Gaina, T. Torsvik, G. Shephard, A. Talsma, M. Gurnis, M. Turner, and S. Maus (2012), Global continental and ocean basin reconstructions since 200

Shephard, G. E., R. D. Müller, and M. Seton (2013), The tectonic evolution of the Arctic since

Sokolov, S., G. Y. Bondarenko, P. Layer, and I. Kravchenko-Berezhnoy (2009), South Anyui suture: tectono-stratigraphy, deformations, and principal tectonic events, Stephan Mueller Special Publication Series, 4, 201-221. https://doi.org/10.5194/smsps-4-201-2009

Sokolov, S. D., G. Y. Bondarenko, O. L. Morozov, V. A. Shekhovtsov, S. P. Glotov, A. V. Ganelin, and I. R. Kravchenko-Berezhnoy (2002), South Anyui suture, northeast Arctic Russia: facts and problems, In E. L. Miller, A. Grantz, S. L. Klemperer (Eds.) Tectonic Evolution of the Bering Shelf-Chukchi Sea-Artic Margin and Adjacent Landmasses (Vol. 360, pp. 209-224), Geological society of America. https://doi.org/10.1130/0-8137-2360-4.209 
585 Thébault, E., C. C. Finlay, P. Alken, C. D. Beggan, E. Canet, A. Chulliat, B. Langlais, V. Lesur, F.

586 J. Lowes, and C. Manoj (2015), Evaluation of candidate geomagnetic field models for IGRF-12, Earth, Planets and Space, 67(1), 112. https://doi.org/10.5047/eps.2010.11.005

588 Toksöz, M. N., \& Hsui, A. T. (1978). Numerical studies of back-arc convection and the formation of marginal basins. Tectonophysics, 50(2-3), 177-196. https://doi.org/10.1016/0040-1951(78)90134-8

591 Toro, J., Amato, J. M., \& Natal'in, B. (2003). Cretaceous deformation, Chegitun River area,

592 Chukotka Peninsula, Russia: Implications for the tectonic evolution of the Bering Strait region. Tectonics, 22(3), 1021. https://doi.org/10.1029/2001TC001333 


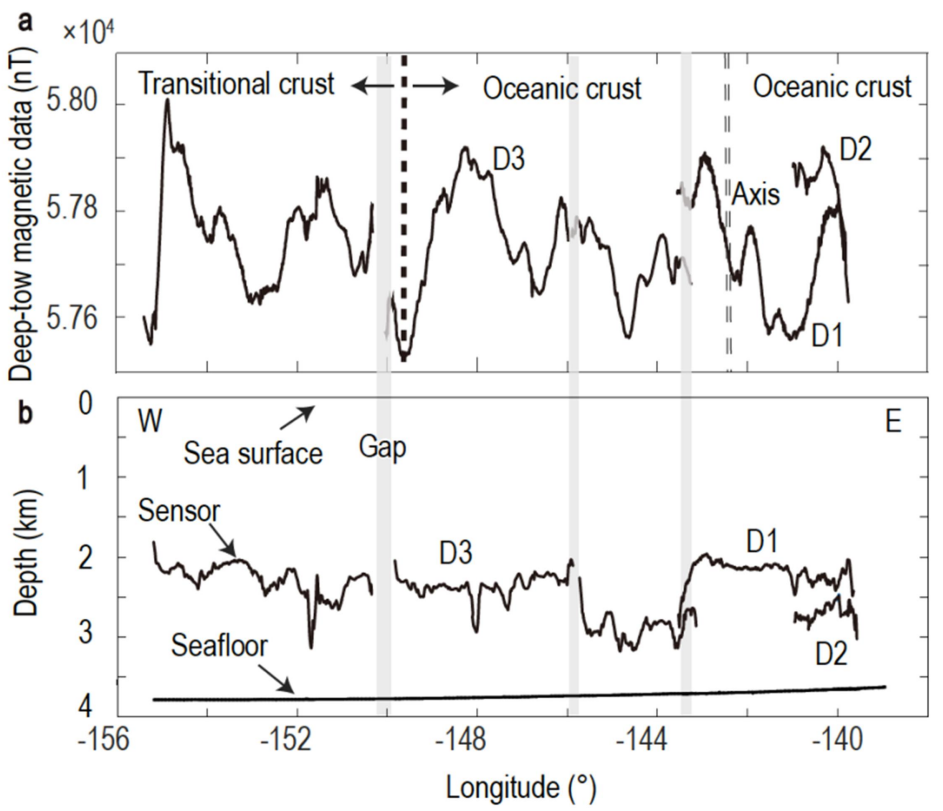

Figure S1. Raw deep-tow magnetic data (a) and depth of the sensor (b). The near E-W trending 598 deep-tow magnetic profile consists of three sections (D1-D3). Section D1 is along $\sim 76.07^{\circ} \mathrm{N}$ and 599 is located $\sim 40 \mathrm{~km}$ north of the other sections.

600 

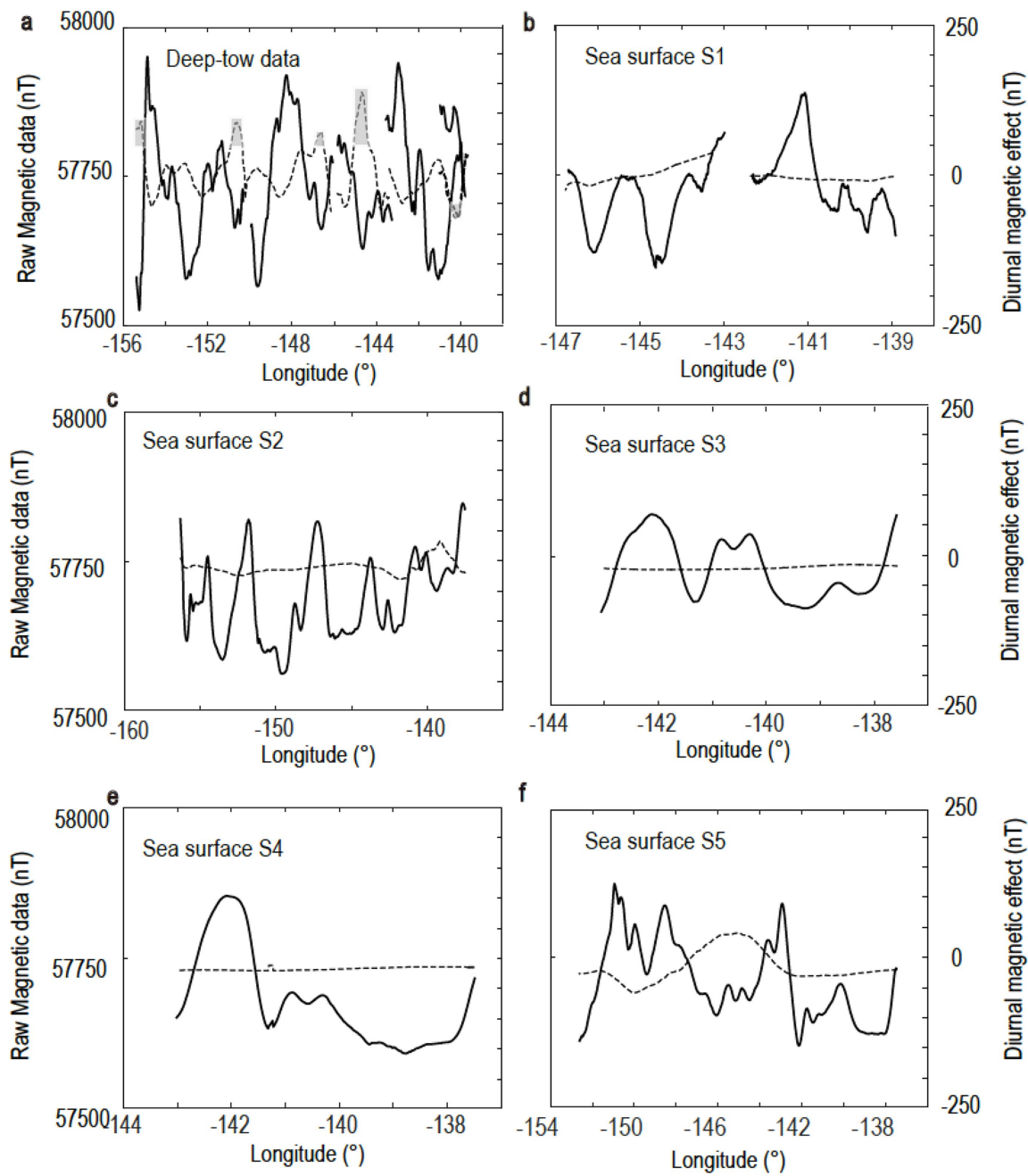

601

602 Figure S2. Comparisons between the raw magnetic data (solid lines) and the diurnal effects

603 (dashed lines).The STD of the diurnal variation for the sea surface surveys in 2016 and 2017 is

$604 \quad 11.3 \mathrm{nT}$ and $14.3 \mathrm{nT}$, respectively. The diurnal variations with amplitudes $>50 \mathrm{nT}$ are covered 605 with gray boxes.

606 


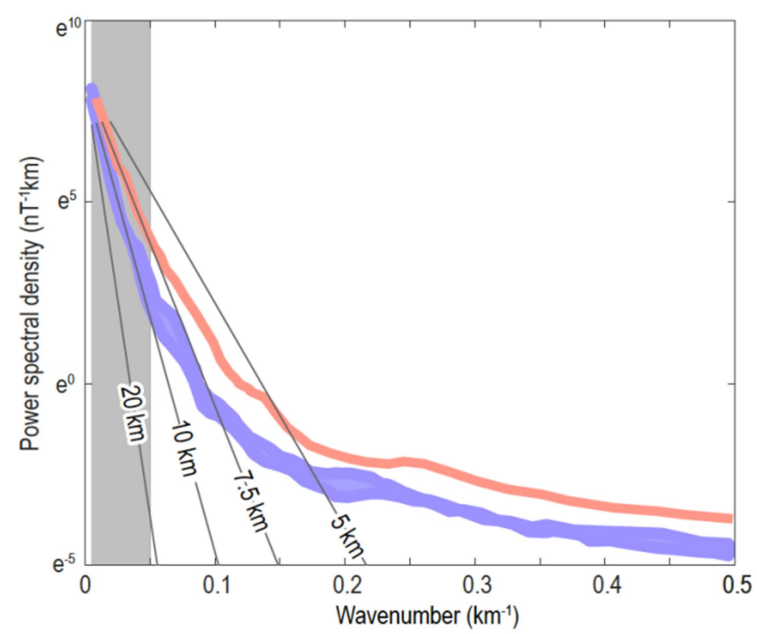

608 Figure S3. Power spectral densities computed from the sea surface (blue) and deep-tow upward

609 continued to sea surface data (red). The blue shaded area represents variance. The gray shaded 610 area indicates thesignals with wavelengths between $20 \mathrm{~km}$ and $300 \mathrm{~km}$, which is most likely due 611 to crustal sources.

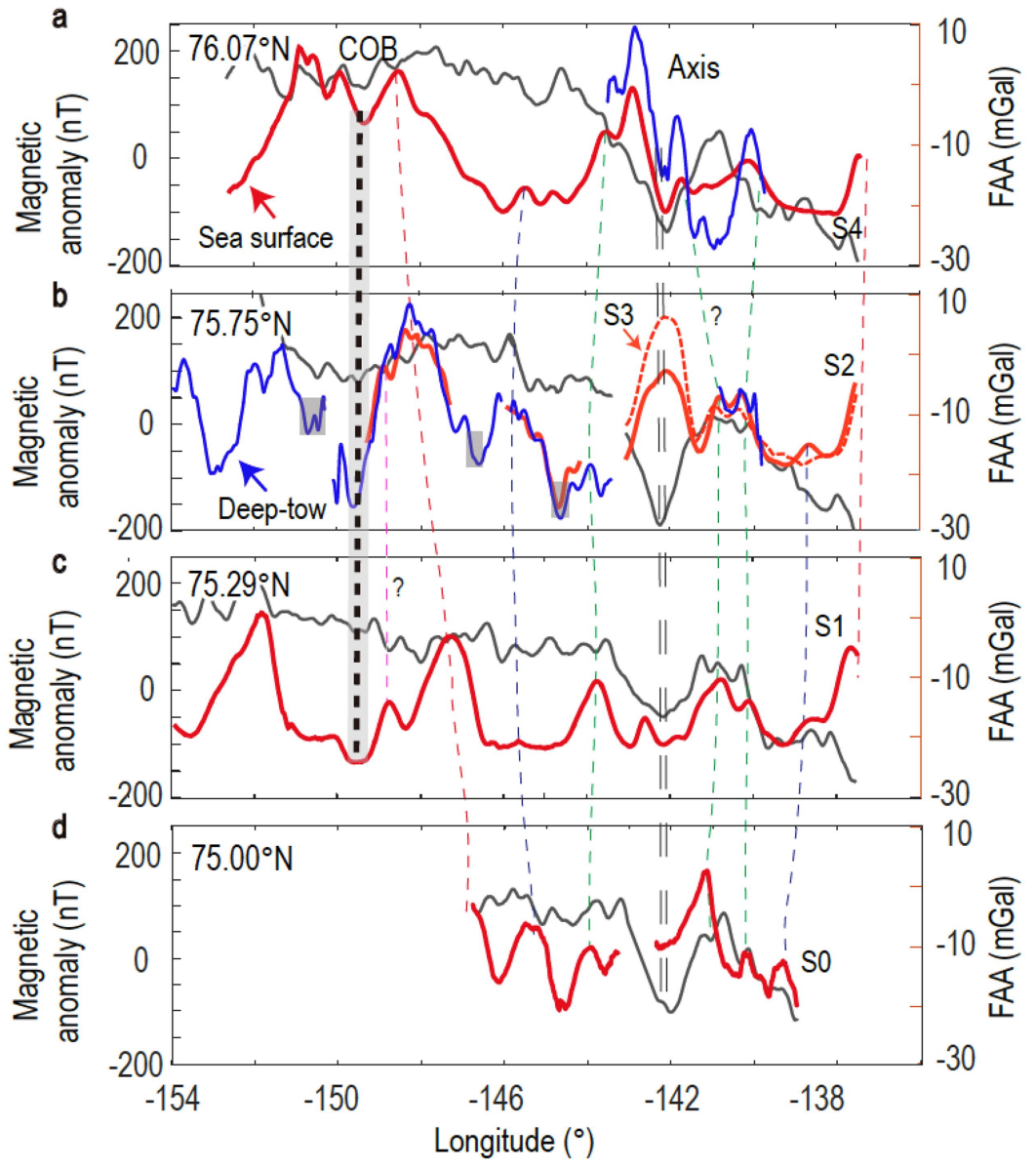


613 Figure S4. Free air anomaly (FAA) along the tracks of magnetic data. The FAA data (black lines)

614 are from Sandwell et al. [2014]. Note that the two broad magnetic highs (N1 and N2) are not

615 correlated with the FAA.

616
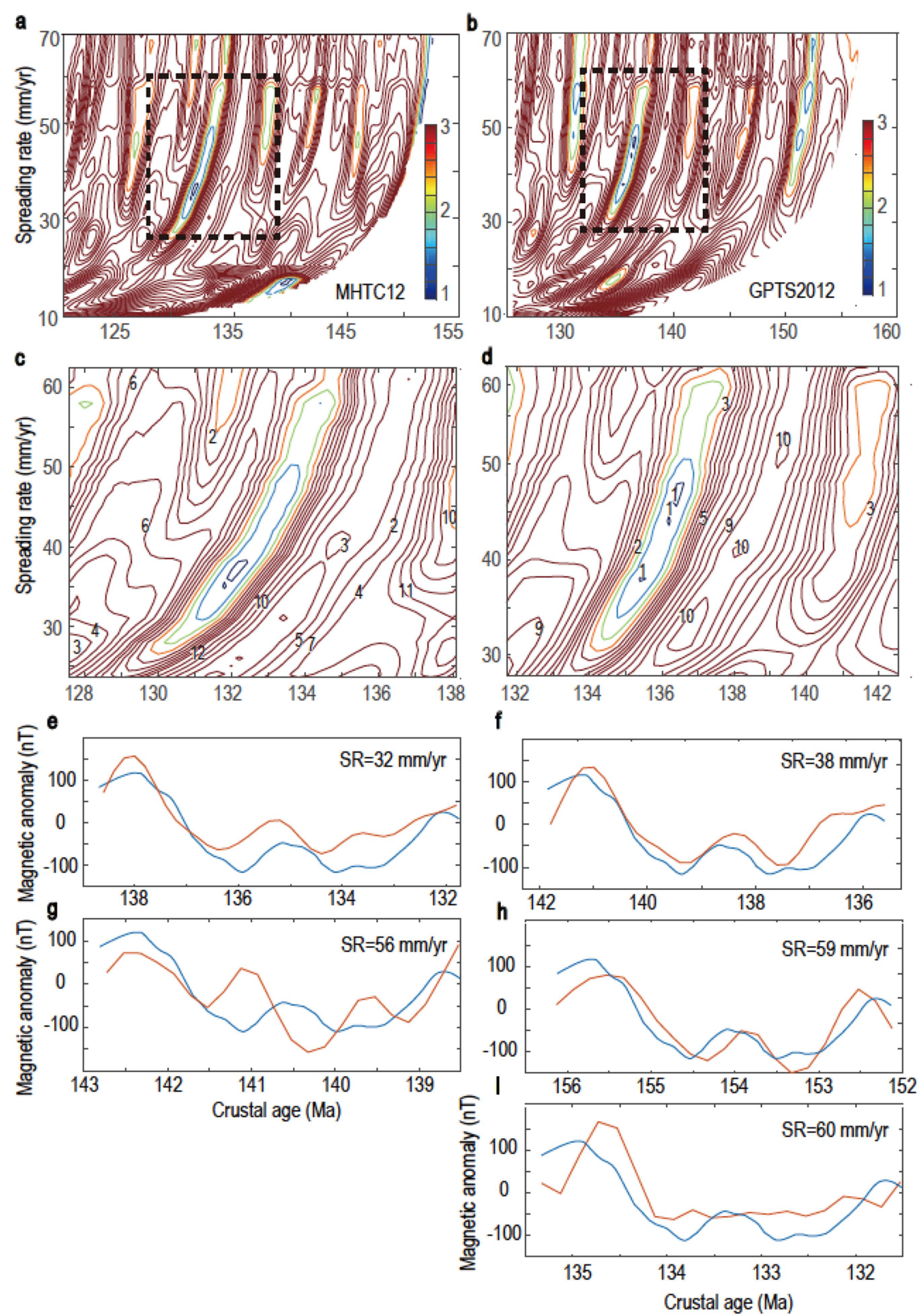

618 Figure S5. Estimation procedure of the best fit sequences. (a-b) Contours of the least-squares

619 misfit of the anomaly between the characteristic stacked data and synthetic data based on 
621 data based on least-squares fitting criteria [DeMets et al., 2010]. In each comparison, the

622 amplitude scale of the synthetic data is adjusted to match the peak-to-trough amplitude of N1 and

623 N2. The contours are normalized by the misfit of the best-fitting least-squares model. (c-d) The contours around the best-fitting model in the dashed frames of (a-b). (e-f) Comparison of the stacked data and best-fitting data based on MHTC12 (e) and GTS2012 (f). (g-i) Comparison of the

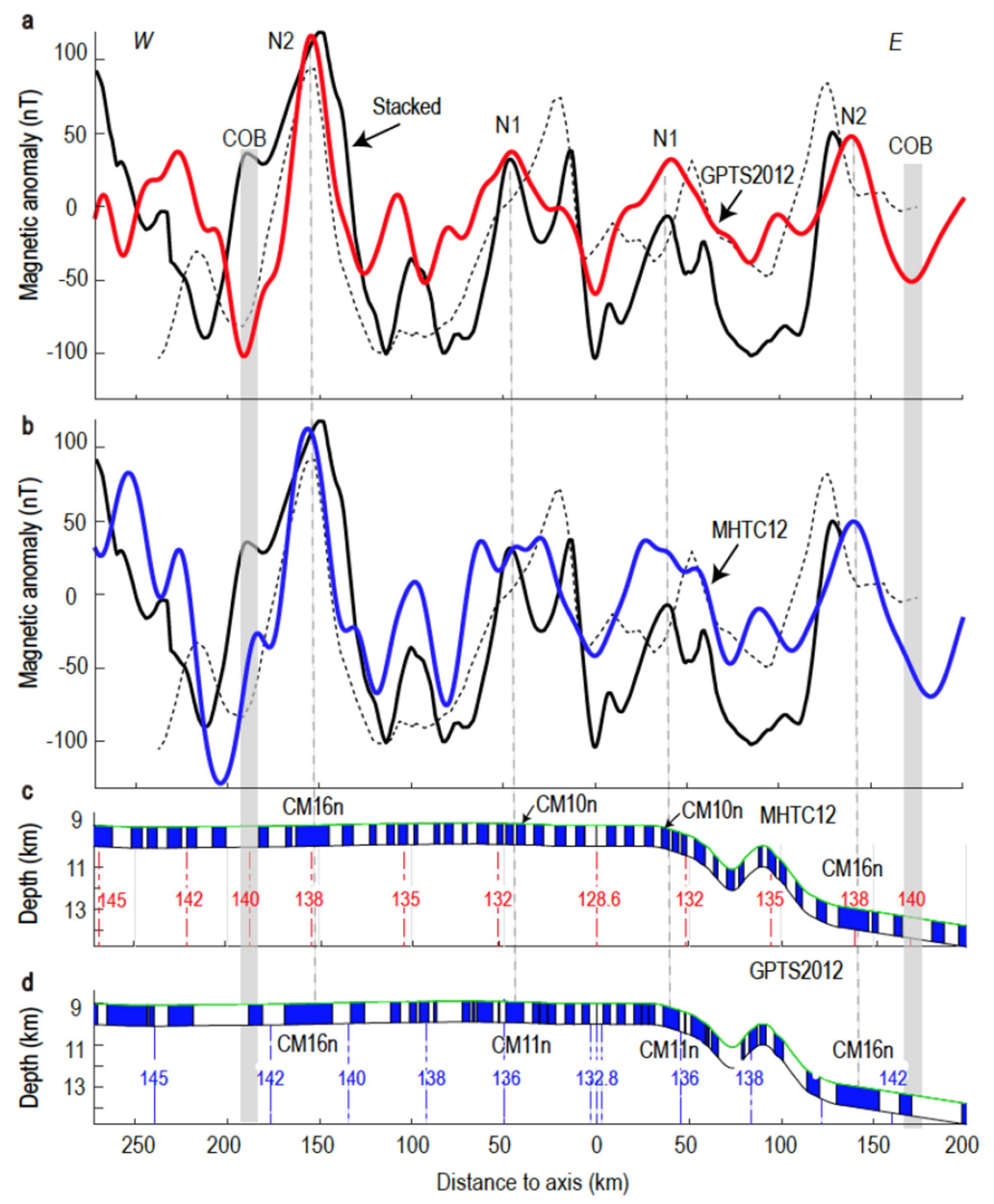

630 Figure S6. Identification of the crustal age in the Canada Basin. (a-b) Comparison between the 
631 stacked magnetic anomalies (black lines) and the best-fitting synthetic magnetic anomalies. The 632 synthetic magnetic anomalies produced by the magnetic bodies in MHTC12 and GTS2012 are 633 shown in red and blue, respectively. Stacked airborne magnetic anomaly is also shown (dashed 634 line). (c-d) The best-fitting magnetic sequences in MHTC12 (c) and GTS2012 (d). 635 